\title{
Biological activity of the essential oils from Cinnamodendron dinisii and Siparuna guianensis
}

\author{
Milene Aparecida Andrade ${ }^{1}$, Maria das Graças Cardoso ${ }^{1}$, Marcos de Souza Gomes ${ }^{1}$, \\ Camila Maria Oliveira de Azeredo ${ }^{2}$, Luís Roberto Batista ${ }^{3}$, Maurilio José Soares ${ }^{2}$, \\ Leonardo Milani Avelar Rodrigues ${ }^{3}$, Ana Cristina S. Figueiredo ${ }^{4}$ \\ ${ }^{1}$ Departamento de Química, Universidade Federal de Lavras, Lavras, MG, Brazil. \\ ${ }^{2}$ Laboratório de Biologia Celular, Instituto Carlos Chagas, Curitiba, PR, Brazil. \\ ${ }^{3}$ Departamento de Ciência dos Alimentos, Universidade Federal de Lavras, Lavras, MG, Brazil. \\ ${ }^{4}$ Faculdade de Ciências de Lisboa, Instituto de Biotecnologia e Bioengenharia, Universidade de Lisboa, \\ Lisboa, Portugal.
}

Submitted: June 19, 2013; Approved: June 6, 2014.

\begin{abstract}
This study had analyzed the antibacterial, antifungal and trypanocidal activity of the essential oils from Cinnamodendron dinisii Schwacke (Canellaceae) and Siparuna guianensis Aublet (Siparunaceae). The essential oils were obtained from fresh leaves by hydrodistillation, using a modified Clevenger apparatus. Chemical analysis by gas-liquid chromatography coupled to mass spectrometry (GC-MS) showed that these essential oils are rich in monoterpene and sesquiterpene hydrocarbons. Activity against the pathogenic bacteria Escherichia coli, Listeria monocytogenes, Pseudomonas aeruginosa, Salmonella choleraesuis and Staphylococcus aureus was evaluated with the agar cavity diffusion method, while activity on the filamentous fungi Aspergillus flavus, Aspergillus niger, Aspergillus carbonarius and Penicillium commune was evaluated by the disk diffusion technique. Trypanocidal activity was tested against Trypanosoma cruzi epimastigotes, using the Tetrazolium salt (MTT) colorimetric assay. Both essential oils exhibited low inhibitory effect towards bacteria, showing high MIC values $\left(125-500 \mu \mathrm{g} \mathrm{m}^{-1}\right)$, with Gram positive bacteria being more susceptible. Better inhibitory effect was obtained for the evaluated fungi, with lower MIC values (7.81-250 $\left.\mu \mathrm{g} \mathrm{mL}^{-1}\right)$, being A. flavus the most susceptible species. Both essential oils presented low trypanocidal activity, with $\mathrm{IC}_{50} / 24 \mathrm{~h}$ values of $209.30 \mu \mathrm{g} \mathrm{mL}^{-1}$ for $S$. guianensis and $282.93 \mu \mathrm{g}$ $\mathrm{mL}^{-1}$ for $C$. dinisii. Thus, the high values observed for the MIC of evaluated bacteria and for $\mathrm{IC}_{50} / 24 \mathrm{~h}$ of $T$. cruzi, suggest that the essential oils have a low inhibitory activity against these microorganisms. In addition, the low MIC values observed for the tested fungi species indicate good inhibitory activity on these microorganisms's growth.
\end{abstract}

Key words: volatile oils, fungi, bacteria, Trypanosoma cruzi.

\section{Introduction}

There is increasing evidence showing the potential of plant constituents as antimicrobial agents. They appear as a source of alternative, efficient and feasible compounds to control growth and survival of microorganisms in diverse areas, such as agriculture, human health, food and cosmetology (Bakkali et al., 2008; Borges et al., 2012). Among the natural compounds with antimicrobial potential we may highlight the essential oils. These compounds are volatile products synthesized from glucose through the secondary metabolism of plants. They are characterized by strong odor and complex composition and can be obtained from different plant structures through hydrodistillation or steam distillation (Dewick, 2002). 
Bacteria are the main microorganisms involved in food contamination processes because they act at different substrate types, wide temperature and $\mathrm{pH}$ ranges, as well as diverse environmental conditions. These microorganisms account for a high number of outbreaks and deaths, causing infections, toxinoses or toxinfections. In smaller proportions, fungi are also responsible for foodborne ilnessess, exploiting food subjected to inadequate storage conditions, producing mycotoxins and/or causing deterioration (Sousa, 2003; Jay, 2005).

The indiscriminate use of antibiotics to control bacteria and fungi led to the emergence of drug-resistant strains. The difficulties to discover and launch new antimicrobials have stimulated research on new synthetic and/or natural antimicrobial compounds, mainly of plant origin (Cowan, 1999).

The protozoan Trypanosoma cruzi is the causer of Chagas disease, an endemic parasitic disease in tropical and subtropical countries of Latin America. This neglected disease affects approximately 10 million people around the world and about 25-100 million people live in areas at risk of infection (WHO, 2010; Salomon, 2012). No vaccine has been discovered up to now for Chagas disease and current treatment with nifurtimox or benznidazole is ineffective due to differences in susceptibility to T. cruzi. Furthermore, these drugs are often poorly tolerated, have serious side effects and efficient only in the acute phase of the disease (Saúde-Guimarães and Faria, 2007; Campos et al., 2009), fact that makes it extremely relevant research aimed at finding effective drugs to combat Chagas disease.

Thus, essential oils appear as an alternative source of antimicrobial agents against spoilage microorganisms, pathogens that cause foodborne illnesses and also the pathogenic protozoan Trypanosoma cruzi, opening new perspectives for the discovery of more effective drugs of plant origin. Essential oils can interact with the microbial membrane and cause drastic physiological changes leading to loss in membrane permeability, ultimately resulting in cell death (Borges et al., 2012). However, due to the large number of components and synergistic or antagonistic interactions among them, it is possible that essential oils have cellular targets other than cell membranes.

The aim of this study was to determine the antibacterial, antifungal and trypanocidal activity of the essential oils from Cinnamodendron dinisii Schwacke and Siparuna guianensis Aublet. Cinnamodendron dinisii (Canellaceae) is an endemic tree from the Brazilian Atlantic Forest, popularly known as "pimenteira" (Peixoto and Barros, 2010), while Siparuna guianensis (Siparunaceae) is a typical bush of the Brazilian cerrado, popularly known as "negramina". Decoction of its leaves is traditionally used to relieve fever and body pain (Valentini et al., 2008).

\section{Material and Methods}

\section{Plant material}

Cinnamodendron dinisii and Siparuna guianensis leaves were collected in February 2011, in the morning, at the Horto de Plantas Medicinais-UFLA (Federal University of Lavras, MG, Brazil) and the UFLA campus, respectively. The collection sites have the following coordinates: C. dinisii: -21 '13'49.0476" latitude, -4458'27.4764" longitude and $933 \mathrm{~m}$ altitude; $S$. guianensis: $-21^{\circ} 13^{\prime} 41.9952^{\prime \prime}$ latitude, $-44^{\circ} 58^{\prime} 9.0048^{\prime \prime}$ and $951 \mathrm{~m}$ altitude.

The collected material was sent to the Laboratory of Organic Chemistry - Essential Oils of the Chemistry Department of UFLA, where mature and healthy leaves with no injuries caused by pathogens, insects or heat stroke were selected. The plant material was properly packed and kept under refrigeration $\left(7^{\circ} \mathrm{C}\right)$ until extraction of essential oils. Species were properly identified and a voucher specimen was deposited at the Herbário ESAL, located in the Biology Department of UFLA, with the following registration numbers: 26,285 (Cinnamodendron dinisii Schwacke) and 26,623 (Siparuna guianensis Aublet).

\section{Essential oils}

Essential oil extraction was performed at the Laboratory of Organic Chemistry - Essential Oils, UFLA, using fresh leaves and a $2 \mathrm{~h}$ distillation period. The extraction method was hydrodistillation, using a modified Clevenger apparatus (Brasil, 2010). The oil was then separated from the hydrolate by centrifugation at $1,100 \mathrm{~g}$ for $5 \mathrm{~min}$, using a horizontal crosspiece benchtop centrifuge. The essential oil was collected, packed in glass bottle and stored under refrigeration $\left(4^{\circ} \mathrm{C}\right)$, protected from light (Guimarães et al., 2008).

\section{Identification and quantification of the essential oil constituents}

The identification of the constituents of the essential oils was performed by gas-liquid chromatography coupled to mass spectrometry (GC-MS), using an Autosystem XL equipped with a DB-1 fused silica column (30 m x $0.25 \mathrm{~mm}$ ID, film thickness $0.25 \mathrm{~m}$; J \& W Scientific Inc.) connected to a Perkin-Elmer Turbomass. The oven temperature was programmed from 45 to $175^{\circ} \mathrm{C}$ in increments of $3{ }^{\circ} \mathrm{C} \mathrm{min}{ }^{-1}$ and subsequently at $15^{\circ} \mathrm{C} \min ^{-1}$ to $300{ }^{\circ} \mathrm{C}$. On reaching $300{ }^{\circ} \mathrm{C}$, the temperature was kept isothermal for $10 \mathrm{~min}$, temperature of the transfer line, $280^{\circ} \mathrm{C}$; temperature of the ionization chamber $220^{\circ} \mathrm{C}$, helium carrier gas, adjusted to a linear velocity of $30 \mathrm{~cm} \mathrm{~s}^{-1}$; split-flow ratio $1: 40$, ionization energy $70 \mathrm{eV}$, ionization current, $60 \mu \mathrm{A}$; mass range, 40$300 \mathrm{U}$, scan time $1 \mathrm{~s}$. The compounds were identified by comparison of their retention indices, relative to those of $n$-alkanes $\mathrm{C}_{9}-\mathrm{C}_{21}$ and by comparison with a library of mass spectra developed in the laboratory of the Centre for Plant 
Biotechnology, Faculdade de Ciências da Universidade de Lisboa-Portugal (Mendes et al., 2011).

The content of each constituent was determined by gas chromatography (GC-FID) in a Perkin Elmer 8700 gas chromatograph equipped with two Flame Ionization Detectors (FID), a data processing system and an injector, in which two columns of different polarity were installed: DB-1 fused silica, with immobilized methylsilicone phase ( $30 \mathrm{~m}$ x $0.25 \mathrm{~mm}$ ID, film thickness $0.25 \mathrm{~m}$; J \& W Scientific Inc.) and DB-17HT fused silica (30 $\mathrm{m} \times 0.25 \mathrm{~mm} \mathrm{ID \text {, }}$ film thickness $0.25 \mathrm{~mm}$; J \& W Scientific Inc.). The oven temperature was programmed from $45^{\circ} \mathrm{C}$ to $175^{\circ} \mathrm{C}$ in increments of $3{ }^{\circ} \mathrm{C} \mathrm{min}{ }^{-1}$ and subsequently at $15^{\circ} \mathrm{C} \mathrm{min}^{-1}$ to $300^{\circ} \mathrm{C}$. On reaching $300{ }^{\circ} \mathrm{C}$, the temperature was kept isothermal for $10 \mathrm{~min}$. Injector and detector temperature, $290{ }^{\circ} \mathrm{C}$ and $280^{\circ} \mathrm{C}$, respectively. Hydrogen was used as carrier gas adjusted to a linear velocity of $30 \mathrm{~cm} \mathrm{~s}^{-1}$. Splitflow ratio of 1:50. The percentage of oil constituents was determined by integration of peak areas without using correction factors. The values shown correspond to the average value of two injections (Mendes et al., 2011).

\section{Antibacterial activity}

Evaluation of the antibacterial activity of the essential oils was performed at the Laboratory of Food Mycology, in the Food Science Department of UFLA. Bacteria used were Staphylococcus aureus ATCC 13565, Listeria monocytogenes ATCC 19117, Escherichia coli ATCC 11229, Salmonella cholerasuis ATCC 6539 and Pseudomonas aeruginosa ATCC 15442.

The bacteria were subcultured in BHI (Brain Heart Infusion) medium and incubated at $37^{\circ} \mathrm{C}$ for $24 \mathrm{~h}$. Aliquots were then transferred to a tube containing $5 \mathrm{~mL}$ of tryptic soy broth (TSB). The tubes were incubated at $37{ }^{\circ} \mathrm{C}$ until reaching turbidity of a $0.5 \mathrm{McF}$ arland standard solution, equivalent to a suspension with $10^{8} \mathrm{cfu} \mathrm{mL}^{-1}$. Turbidity reading was performed using a spectrophotometer (Shimadzu UV-160 1 PC) at a wavelength of $625 \mathrm{~nm}$ (NCCLS, 2003).

Concentration inoculum of $10^{8} \mathrm{CFU} \mathrm{mL}^{-1}$ was determined by the 0.5 McFarland scale, this trial was diluted in the experimental culture medium (Tryptic Soy Agar for Listeria monocytogenes and Mueller-Hinton agar for the other bacteria) until the final concentration of $10^{6} \mathrm{CFU} \mathrm{mL}{ }^{-1}$. Agar inoculated with the bacterial culture was layered on the same agar, previously solidified, where essential oil deposition wells (4 $\mathrm{mm}$ diameter) were made with the aid of glass beads. These wells were filled with $10 \mu \mathrm{L}$ of the essential oil (at 500, 250, 125, 62.5, 31.25, $15.62,7.81$ and $3.90 \mu \mathrm{g} \mathrm{mL}^{-1}$ ) diluted in DMSO. The plates were incubated at $37^{\circ} \mathrm{C}$ for 24 hours and the diameter of the inhibition halos was measured. Three replicates were performed for each treatment, with one control well containing $10 \mu \mathrm{L}$ DMSO (Lima et al., 2012). A solution of $100 \mu \mathrm{g}$
$\mathrm{mL}^{-1}$ chloramphenicol (CL) was used as positive standard to evaluate bacterial sensitivity.

The growth inhibition halo was measured from the circumference of the well to the edge with microorganism growth. From the obtained measurement, which evidenced microorganism sensitivity, it was possible to evaluate bacterial sensitivity at different essential oil concentrations. The minimum inhibitory concentration (MIC) was defined as the lowest essential oil concentration that produced an inhibition halo.

\section{Antifungal activity}

Evaluation of the antifungal activity was performed at the Laboratory of Food Mycology in the Food Science Department, UFLA. The following fungi were used: Aspergillus flavus, Aspergillus carbonarius, Aspergillus niger and Penicillium commune. The fungi were kept at $25^{\circ} \mathrm{C}$ in Malt Extract Agar (MEA) medium.

For the inhibitory effect on filamentous fungi, a disk diffusion test was used, with an inoculum concentration of $10^{6}$ spores $\mathrm{mL}^{-1}$. This inoculum was transferred to a plate containing solidified Malt Extract Agar (MEA) medium, using the surface scattering technique. Filter paper discs ( $4 \mathrm{~mm}$ in diameter) soaked with $10 \mu \mathrm{L}$ of different concentrations of the essential oils $(500,250,125,62.5,31.25$, $15.62,7.81$ or $3.90 \mu \mathrm{g} \mathrm{mL}^{-1}$ ) were placed on the solidified culture medium. A control was made using discs impregnated with $10 \mu \mathrm{L}$ DMSO. A $20 \mu \mathrm{g} \mathrm{mL}^{-1}$ sodium hypochlorite solution was used as positive standard to evaluate fungi sensitivity. The plates were incubated at $25{ }^{\circ} \mathrm{C}$ for $72 \mathrm{~h}$ (Barry and Thornsberry, 1991).

The growth inhibition halo was measured starting from the paper disc circumference to the edge with microorganism growth. Orthogonal measurements were obtained, each one corresponding to the mean of two diametrically opposed measurements. MIC was defined as the lowest essential oil concentration that allowed identification of an inhibition halo.

\section{Trypanocidal activity}

Activity of the essential oils against Trypanosoma cruzi epimastigotes, strain DM28c, was analyzed at the Instituto Carlos Chagas/Fiocruz-PR, Curitiba/PR. Culture epimastigotes were kept at $28{ }^{\circ} \mathrm{C}$ in LIT (Liver InfusionTryptose) medium containing $10 \%$ fetal calf serum (Camargo, 1964). Three-day-old epimastigotes, at the mid-logarithmic phase of growth, were used in the experiments. The essential oils were first solubilized in dimethyl sulfoxide (DMSO) and then diluted to $1 \mathrm{mg} \mathrm{mL}^{-1}$ in LIT medium (stock solution), so that the DMSO concentration never exceeded $1 \%$ in the experiments. Screening was made by serial dilution of the stock solution with LIT in a 96-well ELISA (Enzyme-Linked Immunosorbent Assay) microtiter plate, in a final volume of $20 \mu \mathrm{L}$ for each well. Concentrations used were: 500, 250, 125, 62.5, 31.25, 
15.62, 7.81 and $3.90 \mu \mathrm{g} \mathrm{mL}^{-1}$. After essential oil dilution, $180 \mu \mathrm{L}$ of culture medium with epimastigotes $\left(2.10^{6}\right.$ cells $\left.\mathrm{mL}^{-1}\right)$ was added to each well. Control wells contained $200 \mu \mathrm{L}$ of culture medium with parasites, without the compounds. The plates were incubated for $24 \mathrm{~h}$ at $28{ }^{\circ} \mathrm{C}$ and then $50 \mu \mathrm{L}$ of Tetrazolium salt (MTT) solubilized at $10 \mu \mathrm{g} \mathrm{mL}^{-1}$ in PBS (phosphate buffered saline, $\mathrm{pH}$ 7.2) were added to all wells (final concentration: $2 \mu \mathrm{g} \mathrm{mL}^{-1}$ per well). The plates, wrapped in aluminum foil, were incubated at $37^{\circ} \mathrm{C}$ for $3 \mathrm{~h}$ (Mosmann, 1983).

After the MTT incubation, $50 \mu \mathrm{L}$ of $4 \%$ paraformaldehyde in PBS (pH 7.2) was added to each well. The plate was centrifuged at $2,100 \mathrm{~g}$ for $10 \mathrm{~min}$, the medium was removed by sudden inversion of the plate, the parasites were resuspended in $20 \mu \mathrm{L}$ of $0.01 \mathrm{M} \mathrm{HCl}$ containing $10 \%$ sodium dodecylsulphate (SDS) and the plate was incubated at $37^{\circ} \mathrm{C}$ for 1 hour, or until lysis of all parasites. After adding $80 \mu \mathrm{L}$ DMSO to all wells the plates were incubated at $37{ }^{\circ} \mathrm{C}$ for $30 \mathrm{~min}$, followed by stirring until complete solubilization of the formazan crystals. Reading was performed at $550 \mathrm{~nm}$ in an ELISA reader. The percentage of unviable epimastigotes (\%UE) cells was determined by the equation \%UE $=\left[100\left(A_{c}-A_{s}\right)\right] / A_{c}$, where $A_{c}$ represents the absorbance of the control and $\mathrm{A}_{\mathrm{s}}$ the absorbance of treated cultures. The experiments were performed in triplicate.

The statistical program used was SISVAR (Ferreira, 2008). Data were subjected to analysis of variance. Means were subjected to regression and were also compared by the Scott-Knott test, both at 5\% probability.The adjusted equations were used to calculate the $\mathrm{IC}_{50}$ value and graphs were plotted with values of \% versus concentrations analyzed, using the software Origin 6.0.

\section{Results and Discussion}

The essential oil from $C$. dinisii fresh leaves is composed mainly by monoterpene hydrocarbons $(76.20 \%)$, followed by sesquiterpene hydrocarbons $(10.80 \%)$, with main components $\alpha$-pinene (35.41\%), $\beta$-pinene $(17.81 \%)$, sabinene $(12.01 \%)$ and bicyclogermacrene $(7.59 \%)$. The essential oil from $S$. guianensis fresh leaves contains sesquiterpene hydrocarbons $(41.50 \%)$, oxygenated sesquiterpenes $(19.40 \%)$ and monoterpene hydrocarbons (17.90\%). The main compounds are $\beta$-myrcene $(13.14 \%)$, germacrene-D (8.68\%) and bicyclogermacrene (16.71\%).

Minimum inhibitory concentration values (MICs) of the essential oils for some Gram-positive and Gram-negative bacteria are expressed in Table 1. Both essential oils showed weak inhibitory effect with high MIC values (range: 125.00 to $500.00 \mu \mathrm{g} \mathrm{mL}^{-1}$ ) for Gram-positive bacteria, with no inhibitory effect on Gram-negative bacteria. The Gram-positive bacteria L. monocytogenes and $S$. aureus were more susceptible to the $S$. guianensis essential
Table 1 - Minimum inhibitory concentration (MIC) and lenght of inhibition halos caused by the essential oils from $S$. guianensis (SG) and $C$. dinisii (CD), and by chloramphenicol (CL) at $100 \mu \mathrm{g} \mathrm{mL}^{-1}$ for the evaluated bacteria.

\begin{tabular}{lcccccccc}
\hline & & \multicolumn{2}{c}{$\begin{array}{c}\mathrm{MIC} \\
\left(\mu \mathrm{mL}^{-1}\right)\end{array}$} & & \multicolumn{3}{c}{$\begin{array}{c}\text { Inhibition halo } \\
(\mathrm{mm})\end{array}$} \\
\cline { 3 - 6 } \cline { 7 - 9 } Bacteria & Gram & $\mathrm{SG}$ & $\mathrm{CD}$ & & $\mathrm{SG}$ & $\mathrm{CD}$ & $\mathrm{CL}$ \\
\hline S. aureus & + & 125.00 & 250.00 & & 5.30 & 5.30 & 25.20 \\
L. monocytogenes & + & 250.00 & 500.00 & & 6.00 & 5.60 & 23.50 \\
E. coli & - & 500.00 & $\mathrm{NI}$ & & 5.30 & - & 14.80 \\
P. aeruginosa & - & $\mathrm{NI}$ & 500.00 & & - & 6.00 & 20.00 \\
S. cholerasuis & - & $\mathrm{NI}$ & $\mathrm{NI}$ & & - & - & 18.90 \\
\hline
\end{tabular}

*NI: no inhibition.

oil at the evaluated concentrations. All tested bacteria were sensitive to $100 \mu \mathrm{g} \mathrm{mL}^{-1}$ chloramphenicol.

A higher susceptibility of Gram-positive bacteria, as compared to Gram-negative bacteria, towards essential oils has been already observed (Burt, 2004). Gram-negative bacteria have an outer membrane with lipopolysaccharide molecules, resulting in a hydrophilic surface (Burt, 2004). Thus, the outer membrane acts as a barrier to penetration of macromolecules and hydrophobic compounds, making Gram-negative bacteria relatively resistant to antibiotics and other hydrophobic drugs, such as essential oils.

The essential oils from C. dinisii and S. guianensis are rich in monoterpene and sesquiterpene hydrocarbons. Since these molecules are hydrophobic (Burt, 2004), they probably move from the aqueous phase into cell membranes, causing toxic effects to the bacterial membrane structure and function. Furthermore, essential oils make cell membranes permeable to compounds that usually are unable to cross intact membranes, thus promoting changes in cytoplasmic density and coagulation of some cytoplasmic components. This damage may ultimately lead to bacterial cell death (Cox et al., 2001).

Evaluation of the bacteriostatic and bactericidal activity of the monoterpenes $\alpha$ - and $\beta$-pinene, (R and S)limonene, 1,8-cineole and borneol towards Listeria monocytogenes showed that $\alpha$-pinene was the most active component, with $\mathrm{MIC}=0.019 \%$ for this microorganism (Mourey and Canillac, 2002). Thus, the antibacterial activity of the essential oil from $C$. dinisii towards L. monocytogenes here observed may be related to the high content (35.41\%) of $\alpha$-pinene in this essential oil.

MIC values with the tested fungi are expressed in Table 2. Both essential oils were active against all evaluated fungi, with inhibitory concentration ranging from 7.81 to $250 \mu \mathrm{g} \mathrm{mL}^{-1}$. The essential oil from S. guianensis was more effective, with lower MIC values. The species A. flavus showed a higher sensitivity for the $S$. guianensis essential oil and $P$. comune for the $C$. dinisii essential oil, while 
Table 2 -

Minimum inhibitory concentration (MIC) and lenght of inhibition halos caused by the essential oils from $S$. guianensis (SG) and C. dinisii (CD), and by sodium hypochlorite (SH) at $20 \mu \mathrm{g} \mathrm{mL}^{-1}$ for the evaluated fungi.

\begin{tabular}{lccccc}
\hline & \multicolumn{2}{c}{ MIC $\left(\mu \mathrm{g} \mathrm{mL}^{-1}\right)$} & \multicolumn{3}{c}{ Inhibition halo $(\mathrm{mm})$} \\
Fungi & $\mathrm{SG}$ & $\mathrm{CD}$ & $\mathrm{SG}$ & $\mathrm{CD}$ & $\mathrm{SH}$ \\
\hline A. flavus & 7.81 & 125.00 & 6.70 & 6.30 & 25.70 \\
A. carbonarius & 125.00 & 250.00 & 7.00 & 6.30 & 17.20 \\
A. niger & 31.25 & 62.50 & 6.00 & 6.00 & 19.20 \\
P. comune & 31.25 & 31.25 & 7.00 & 6.70 & 31.00 \\
\hline
\end{tabular}

A. carbonarius was the most resistant fungal species, when compared to both evaluated essential oils. All microorganisms were sensitive to $20 \mu \mathrm{g} \mathrm{mL} \mathrm{m}^{-1}$ sodium hypochlorite.

Montanari et al. (2010) showed that $S$. guianensis essential oil inhibited growth of C. albicans, Criptococcus neoformans, Trychophyton rubrum and A. fumigatus at low concentrations, especially the fungus $C$. neoformans $\left(16 \mu \mathrm{g} \mathrm{mL}^{-1}\right)$. The antifungal properties of the essential oil from Pleodendron costaricense (Canellaceae), which presents $\alpha$ - and $\beta$-pinene, $\beta$-myrcene, $\beta$-thujene, and $\beta$-caryophyllene as major compounds, was also evaluated, with high activity against Alternaria alternata, Candida albicans and Wangiella dermatitidis (Amiguet et al., 2006). Our data corroborate these studies regarding the antifungal potential for $S$. guianensis and in the case of C. dinisii, for plants belonging to the Canellaceae family.

As for bacteria, the mechanism of inhibitory action of essential oils on fungi is based on their lipophilicity. Their interference on composition or tridimensional arrangement of the microbial plasma membrane will render it devoid of the basic structure for homeostatic balance and optimal physiological functioning. Furthermore, ergosterol is present in fungal membranes, acting as a membrane fluidity modulator. Chemically it is classified as a highly lipophilic membrane steroid and any action of essential oils on this molecule may trigger an imbalance in fluidity of the fungal plasma membrane, leading to changes in intracellular homeostasis (Souza et al., 2003).

Both essential oils showed weak inhibitory effect on the protozoan $T$. cruzi, with increased unviability of epimastigotes observed with increasing concentrations of both essential oils after $24 \mathrm{~h}$ of treatment (Table 3 ). Best activity was obtained for $S$. guianensis $\left(\mathrm{IC}_{50} / 24 \mathrm{~h}=209.30 \mu \mathrm{g} \mathrm{mL}^{-1}\right)$, followed by $C$. dinisii $\left(\mathrm{IC}_{50} / 24 \mathrm{~h}=282.93 \mathrm{mg} \mathrm{mL}^{-1}\right)$. These values are high, when compared to that obtained with the reference compound benznidazol $\left(\mathrm{IC}_{50} / 24 \mathrm{~h}=12.8 \mu \mathrm{g} \mathrm{mL}^{-1}\right)$ (Lamas et al., 2006).

This is the first report on the trypanocidal activity of the essential oil extracted from C. dinisii and S. guianensis leaves. There is increasing evidence that essential oils, as well as their constituents, present biological activity against pathogenic trypanosomatids (Anthony et al., 2005; Alvino
Table 3 - Activity of essential oils from $S$. guianensis and $C$. dinisii on Trypanosoma cruzi epimastigote forms.

Unviable epimastigote cells (\%)

\begin{tabular}{lcc} 
Concentration $\left(\mu \mathrm{g} \mathrm{mL}^{-1}\right)$ & S. guianensis & C. dinisii \\
\hline 3.90 & $0.36 \mathrm{a}$ ** & $3.37 \mathrm{a}$ \\
7.81 & $2.10 \mathrm{a}$ & $8.39 \mathrm{~b}$ \\
15.62 & $9.50 \mathrm{~b}$ & $10.57 \mathrm{c}$ \\
31.25 & $21.73 \mathrm{c}$ & $13.22 \mathrm{c}$ \\
62.50 & $25.34 \mathrm{c}$ & $15.04 \mathrm{c}$ \\
125.00 & $45.80 \mathrm{~d}$ & $24.78 \mathrm{~d}$ \\
250.00 & $84.28 \mathrm{e}$ & $36.89 \mathrm{e}$ \\
500.00 & $86.81 \mathrm{e}$ & $87.96 \mathrm{f}$ \\
$\mathrm{IC}_{50} / 24 \mathrm{~h}\left(\mu \mathrm{g} \mathrm{mL}^{-1}\right)^{*}$ & 209.30 & 282.93
\end{tabular}

* $\mathrm{IC}_{50}=$ Concentration that causes lysis or death of $50 \%$ of the population of $T$. cruzi epimastigotes in $24 \mathrm{~h}$. ** Mean values in a column followed by the same letter do not differ by the Scott-Knott test at 5\% significance.

et al., 2012). It has been proposed that the activity of essential oils on trypanosomatids is mainly due to terpene composition (Borges et al., 2012). Terpenes are responsible for the hydrophobic character of essential oils, thus allowing their diffusion through the parasite cell membrane, affecting intracellular metabolic pathways and organelles. Accordingly, it has been shown that citral, an oxygenated terpene found in the volatile oil of Cymbopogum citratus, presents activity against $T$. cruzi (Santoro et al., 2007), possibly by inducing cell membrane lysis, with leakage of cytoplasm. Although oxygenated terpenes are found in small proportions in the essential oil from C. dinisii (12\% monoterpenes and oxygenated sesquiterpenes) and S. guianensis (19.40\% oxygenated sesquiterpenes), it is possible that these compounds are associated to the trypanocidal activity of these essential oils in a synergistic behavior.

\section{Conclusion}

The essential oils of Cinnamodendron dinisii and Siparuna guianensis presented small inhibitory effect on bacteria, showing high MIC values (125-500 $\mu \mathrm{g} \mathrm{mL}^{-1}$ ) or even no inhibition, especially for Gram-negative bacteria. The tested microorganisms were less sensitive to the essential oil from $C$. dinisii in the evaluated concentrations.

The essential oils presented inhibitory effect for the evaluated fungi, with low MIC values (7.81-250 $\left.\mathrm{g} \mathrm{mL}^{-1}\right)$. In the evaluated concentrations, the tested microorganisms were less sensitive to the essential oil from $C$. dinisii.

Growth inhibition of Trypanosoma cruzi epimastigotes allowed to determine an $\mathrm{IC}_{50} / 24 \mathrm{~h}$ value of $282.93 \mu \mathrm{g} \mathrm{mL}^{-1}$ for $C$. dinisii and $209.30 \mu \mathrm{g} \mathrm{mL}^{-1}$ for $S$. guianensis. These values are high, when compared to that obtained with the reference compound benznidazol $\left(\mathrm{IC}_{50} / 24 \mathrm{~h}=12.8 \mu \mathrm{g} \mathrm{mL}^{-1}\right)$. 


\section{Acknowledgments}

To the Conselho Nacional de Desenvolvimento Científico e Tecnológico (CNPq), the Fundação de Apoio à Pesquisa e Extensão de Minas Gerais (FAPEMIG), to Coordenação de Aperfeiçoamento de Pessoal de Nível Superior, to Pest $\mathrm{OE} / \mathrm{EQB} / \mathrm{LA} 0023 / 2011$ and Fundação Oswaldo Cruz (FIOCRUZ) for financial aid and grants provided.

\section{References}

Alviano DS, Barreto ALS, Dias FA et al. (2012) Conventional therapy and promising plant-derived compounds against trypanosomatid parasites. Front Microbiol 3:1-10.

Amiguet VT, Petit P, Ta CA et al. (2006) Phytochemistry and antifungal properties of the newly discovered tree Pleodendron costaricense. J Nat Prod 69:1005-1009.

Anthony JP, Fyfe L, Smith H (2005) Plant active components - A resource for antiparasitic agents? Trends Parasitol 21:462468.

Bakkali F, Averbeck S, Averbeck D et al. (2008) Biological effects of essential oils - A review. Food Chem Toxicol 46:446-475.

Barry AL, Thornsberry C (1991) Susceptibility tests: diffusion test procedures. In: Balows A, Hausler Jr WJ, Herrmann KL et al. (eds) Manual of Clinical Microbiology. American Society for Microbiology, Washington, pp 1117-1125.

Borges AR, Aires JR, Higino TM et al. (2012) Trypanocidal and cytotoxic activities of essential oils from medicinal plants of Northeast of Brazil. Exp Parasitol 132:123-128.

Brasil (2010) Agência Nacional de Vigilância Sanitária. Farmacopeia Brasileira. 5 ed. Anvisa, Brasília, pp 198-199.

Burt S (2004) Essential oils: their antibacterial properties and potential applications in foods - A review. Int J Food Microbiol 94:223-253.

Camargo, EC (1964) Growth and differentiation in Trypanosoma cruzi. Origin of metacyclic trypanosomes in liquid media. Rev. Inst. Med. Trop. Sao Paulo 6:93-100.

Campos FM, Liarte DB, Mortara RA et al. (2009) Characterization of a gene encoding alcohol dehydrogenase in benznidazole-susceptible and -resistant populations of Trypanosoma cruzi. Acta Trop 111:56-63.

Cowan MM (1999) Plant products as antimicrobial agents. Clin Microbiol Rev 12:564-582.

Cox SD, Mann CM, Markham JL (2001) Interactions between components of the essential oil of Melaleuca alternifolia. J Appl Microbiol 91:492- 497.

Dewick PM (2002) Medicinal Natural Products: A Biosynthetic Approach. 3th edition. J. Wiley, Chichester, pp 7-12.

Ferreira DF (2008) SISVAR: um programa para análises e ensino de estatística. Rev Cient Symposium 6:36-41.

Guimarães LGL, Cardoso MG, Zacaroni LM et al. (2008) Influência da luz e da temperatura sobre a oxidação do óleo essencial de capim-limão (Cymbopogon citratus (D.C.) Stapf). Quím Nova 31:1476-1480.

Jay JM (2005) Microbiologia de Alimentos. 6th edition. Artmed, Porto Alegre.

Lamas MC, Villaggi L, Nocito I et al. (2006) Development of parenteral formulations and evaluation of the biological ac- tivity of the trypanocide drug benznidazole. Int J Pharm 307:239-243.

Lima RK, Cardoso MG, Andrade MA et al. (2012) Bactericidal and antioxidant activity of essential oils from Myristica fragrans Houtt and Salvia microphylla H.B.K. J Am Oil Chem Soc 89:523-528.

Mendes MD, Lima AS, Trindade H et al. (2011) ISSR molecular characterization and leaf volatiles analysis of Pittosporum undulatum Vent. naturalized in the Azores archipelago (Portugal). Ind. Crops Prod 33:710-719.

Montanari RA (2010) Composição química e atividades biológicas dos óleos essenciais de espécies de Anacardiaceae, Siparunaceae e Verbenaceae. Dr. Sc. Thesis, Universidade Federal de Viçosa, Viçosa, 159 pp.

Mosmann T (1983) Rapid colorimetric assay for cellular growth and survival. J Immunol Methods 65:55-63.

Mourey A, Canillac N (2002) Anti-Listeria monocytogenes activity of essential oils components of conifers. Food Control 13:289-292.

National Committee for Clinical Laboratory Standards (2003) Methods for Dilution Antimicrobial Susceptibility Tests for Bacteria that Grow Aerobically: Approved Standard. 6th edition. Clinical and Laboratory Standards Institute, Wayne, pp 27-38.

Peixoto AL, Barros F (2010) Canellaceae. In: Lista de Espécies da Flora do Brasil. Jardim Botânico do Rio de Janeiro, Rio de Janeiro. Available at: http://floradobrasil.jbrj.gov.br/2010/FB111724 Accessed October 12, 2011.

Salomon CJ (2012) First century of Chagas' disease: an overview on novel approaches to nifurtimox and benznidazole delivery systems. J Pharm Sci 101:888-894.

Santoro GF, Cardoso MG, Guimarães LG et al. (2007) Antiproliferative effect of the essential oil of Cymbopogon citratus (DC) Stapf (lemongrass) on intracellular amastigotes, bloodstream trypomastigotes and culture epimastigotes of Trypanosoma cruzi (Protozoa, Kinetoplastida). Parasitol 134:1649-1656.

Saude-Guimaraes DA, Faria AR (2007) Substâncias da natureza com atividade anti-Trypanosoma cruzi. Rev Bras Farmacogn 17:455-465.

Sousa CP (2003) Pathogenicity mechanisms of prokaryotic cells: An evolutionary view. Braz J Infect Dis 7:23-31.

Souza EL, Lima EO, Narain N (2003) Especiarias: uma alternativa para o controle da qualidade sanitária e de vida útil de alimentos, frente às novas perspectivas da indústria alimentícia. Higiene Alimentar 17:38-42.

Valentini CMA, Almeida JD, Coelho MFB et al. (2008) Uso de Siparuna guianensis Aublet (negramina) em Bom Sucesso, município de Várzea Grande, Mato Grosso. Rev Biol Neotrop 5:11-22.

World Health Organization (2010) Chagas disease (American trypanosomiasis). Fact Sheet no. 340. Avaliable at http://www.who.int/mediacentre/factsheets/fs340/en/index.html. Accessed 10 December 2012.

Associate Editor: Elaine Cristina Pereira De Martinis

All the content of the journal, except where otherwise noted, is licensed under a Creative Commons License CC BY-NC. 